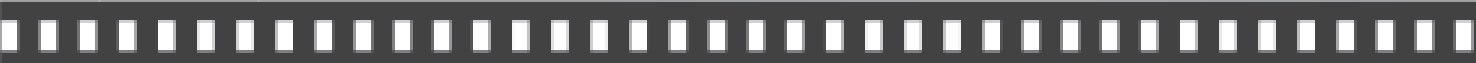

\author{
Efeitos da ekphrasis e da fanopeia na \\ representação cinematográfica de Os eleitos
}

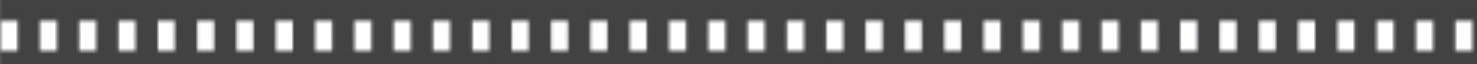

Silvio Ricardo Demétrio

Gisele Krodel Rech

Artigo recebido em: 06/02/2014

Artigo aprovado em: 15/05/2014 


\title{
Efeitos da ekphrasis e da fanopeia na representação cinematográfica de 0 s eleitos
}

Ekphrasis' and Fanopeia's Effects in the cinematic representation of The RighStuff

\author{
Silvio Ricardo Demétrio* \\ Gisele Krodel Rech **
}

\begin{abstract}
Resumo: O presente artigo propõe a análise de uma sequência do filme Os eleitos (The rightStuff, 1983), de Philip Kaufman, fazendo a partir dela uma relação análoga com o texto de Tom Wolfe no livroreportagem de mesmo nome, que inspirou a película. Com base nos conceitos provenientes da retórica e da teoria literária - leia-se ekphrasis e fanopeia -, que versam sobre as representações literárias de imagens e vice-versa, pretende-se buscar aproximações e distanciamentos entre as obras nas diferentes formas de arte literatura e cinema. A intenção é criar uma sistemática de representação, que passa pelo imaginário do diretor ao interpretar e adaptar o livro de Tom Wolfe, que por sua vez usou o jornalismo literário para registrar a odisseia do Projeto Mercury e a missão dos primeiros astronautas da Nasa.
\end{abstract}

Palavras-chave: Jornalismo Literário. Os eleitos. Cinema. Ekphrasis. Fanopeia.

\begin{abstract}
This article proposes an analysis of a sequence of the film The rightStuff, 1983, by Philip Kaufman, making from it a parallel with the text of Tom Wolfe in the book-entry of the same name, which inspired the film. Based on concepts from rhetoric and literary theory - read ekphrasis and fanopeia - which deal with literary representations of images and vice-versa, we intend to seek similarities and differences between works in different art forms - literature and cinema. The intention is to create a system of representation, which passes through the directos's imaginary to interpret and adapt the book by Tom Wolfe, who used the literary journalism to register the odyssey Mercury Project and the mission of the first NASA astronauts.
\end{abstract}

Keywords: Literary journalism. The RighStuff. Cinema. Ekphrasis. Fanopeia.

* Doutor em Epistemologia da Pesquisa em Comunicação pela Universidade de São Paulo (USP). Mestre em Ciências da Comunicação pela USP. Graduado em Comunicação Social - Jornalismo pela Universidade Estadual de Londrina (UEL). Professor adjunto da UEL na graduação em Comunicação Social - Jornalismo e no programa de Pós-Graduação em Comunicação. E-mail: silviodemetrio@uol.com.br

**Mestre em Comunicação pela Universidade Estadual de Londrina (UEL). Especialista em Gestão e Produção de Rádio e Televisão pela Universidade Tuiuti do Paraná. Graduada em Comunicação Social - Jornalismo pela Pontifícia Universidade Católica do Paraná (PUC/PR). Professora do curso de Comunicação Social - Jornalismo da UEL. E-mail: krodelrech@gmail.com 


\section{Introdução}

Os primeiros jornais tinham nos escritores seus protagonistas faziam as vezes de redatores e publicavam obras por meio dos periódicos. Depois, com o surgimento da deontologia e da profissão de jornalista, as áreas se distanciaram. Literatura passou a ser vinculada à ficção e jornalismo aos temas não ficcionais - ou ainda à representação da realidade. No entanto, a aproximação entre os dois, de modo recorrente, se manifesta por meio do jornalismo literário, que se vale do uso de recursos estilísticos da literatura na narração de matéria não ficcional.

A prática jornalístico-literária experimentou um período extremamente criativo por meio dos escritores que militaram à época do fenômeno do New Journalism, cujos trabalhos se fortaleceram na efervescência do período contracultural, que marcou os Estados Unidos em especial da década de 1960. O escritor Tom Wolfe fez parte desse grupo e já no final dos anos 70, lançou Os eleitos, que inspirou o diretor Philip Kaufman a produzir uma versão cinematográfica da história do Projeto Mercury, desenvolvido pela Nasa nos anos 60 . Como pano de fundo da história dos audaciosos pilotos que se tornaram os primeiros astronautas a irem ao espaço, está a disputa espacial entre Estados Unidos e a então União Soviética, no auge da Guerra Fria.

No presente artigo, analisa-se uma sequência do filme, buscando encontrar nos elementos visuais as evocações imagéticas das palavras contidas no livro, identificando neste percurso como se dá a tradução de palavras em imagens. Para tanto, o ponto de partida é entender a obra jornalístico-literária e suas características narrativas. O fenômeno do New Journalism, ao qual Tom Wolfe está vinculado, se fortaleceu nos Estados Unidos nos anos 60, como uma resposta ao jornalismo pautado pela objetividade, imparcialidade e com fórmulas prontas, incluindo conceitos como lead e pirâmide invertida. Sobre o New Jornalism, Johnson diz que, 
A través de su nueva consciência y su nuevo linguaje ha comunicado una información más fresca y más útil sobre los câmbios registrados en nuestro mundo y, de um modo o outro, se ha mostrado más cabal, más honesto y más inteligentemente crítico que el periodismo tradicional. (JOHNSON, 1975. p.16) ${ }^{1}$

Encabeçado por nomes como, além do próprio Wolfe, Gay Talese, Truman Capote e Hunter Thompson, o New Journalism resgatou o conceito narrativo-literário na reprodução de fatos reais, ora em reportagens publicadas em revistas norte-americanas como a Esquire, ora em livro-reportagens - muitas vezes compilações de grandes reportagens já publicadas. Além do maior rebuscamento narrativo, as mesmas eram escritas com profundo esmero descritivo, muito em função do fato de serem fruto da observação testemunhal da realidade - dentre as funções de um jornalista, está a de transmitir aos seus receptores elementos suficientes para que ele consiga visualizar mentalmente detalhes da cena onde ocorre uma ação.

Para Wolfe (2005), o trabalho de escrever consistia em "mergulhar fundo na aventura de retirar a narrativa jornalística do limbo e transformála, através de técnicas ficcionais e intensíssimos esforços de reportagem, em objeto literário e documental de primeira grandeza". A nova descoberta dos jornalistas-escritores ganhou força e, segundo Wolfe,

No começo dos anos 60, uma curiosa idéia nova, quente o bastante para inflamar o ego, começou a se insinuar nos estreitos limites da statusfera das reportagens especiais. Tinha um ar de descoberta. Essa descoberta, de início, modesta, na verdade, reverencial, poderíamos dizer, era que talvez fosse possível escrever jornalismo para ser... lido como romance (WOLFE, 2005, p.19).

A despeito de não ser considerado oficialmente o fundador do estilo, foi Wolfe (2005) quem escreveu uma espécie de manifesto do New

1 Através de sua nova consciência e sua nova linguagem comunicava uma nova informação mais fresca e mais útil sobre as mudanças registradas em nosso mundo e, de um modo ou de outro, se mostrou mais cabal, mais honesto e mais inteligentemente crítico do que o jornalismo tradicional (tradução nossa). 
Journalism, onde admite que o movimento se organizou movido muito mais pelo instinto do que necessariamente pautado por uma teoria ou metodologia de produção. No entanto, apesar do posicionamento enfático, ele registrou quatro recursos básicos que, de uma maneira ou outra, podemos identificar como recorrentes nas obras dos autores vinculados ao movimento.

O primeiro era a construção cena a cena, o que tornava de suma importância o se colocar no local onde se desenrolava a narrativa - no caso de Wolfe, na região de origem dos pilotos de caça e posteriormente no Cabo Canaveral, onde se desenvolveu o Projeto Mercury. Em suma, o autor se valia de verdadeira testemunha dos fatos. Uma vez no local das cenas, o autor também fazia o registro dos diálogos completos, obtidos por meio de entrevistas. O ato de dar voz ao outro - ou a outros personagens - resultava no terceiro recurso, que era apresentar cenas pelos pontos de vistas de diferentes personagens. Por fim, o autor precisava registrar hábitos, roupas, gestos, maneiras de viajar, comer, modo de se comportar com superiores, inferiores e outras características simbólicas dos personagens, em verdadeira contextualização do texto jornalísticoliterário para o ambiente que estava sendo retratado. Para Wolfe (2005, p.55), 'o registro desses detalhes não é mero bordado em prosa. Ele se coloca junto ao centro do poder do realismo'.

Uma observação mais acurada desses quatro pontos não os colocaria, por obséquio, intimamente próximos de uma descrição aprofundada e detalhada transposta para o texto escrito? Desta feita, o leitor não teria riqueza de elementos para visualizar os detalhes da história? É nesse ponto, da descrição, que se percebe uma aproximação com os conceitos da fanopeia e da ekphrasis.

O crítico literário e poeta Ezra Pound (2007, p.23) abre o seu $A B C$ da Literatura (ABC of Reading), publicado pela primeira vez em 1934, afirmando que "o método adequado para o estudo da poesia e da literatura é o método dos biologistas contemporâneos, a saber exame cuidadoso e direto da matéria". Em síntese, a ideia é olhar para um texto ou uma obra de modo aprofundado, como verdadeira visão microscópica. Para o autor, 
este procedimento deveria ser tomado pelo fato de a literatura ser carregada de significado - e só com este destrinchamento seria possível alcançar verdadeira análise crítica do texto. Segundo Pound,

[...] o bom escritor escolhe as palavras pelo seu 'significado'. Mas o significado não é algo tão definido e predeterminado como o movimento do cavalo ou do peão num tabuleiro de xadrez. Ele surge com raízes, com associações, e depende de como e quando a palavra é comumente usada ou de quando ela tenha sido usada brilhante ou memoravelmente (POUND, 2007, p.40).

É nesse jogo de escolhas e aplicações dos lexemas, pois, que em tese resulta no que o autor chama de grande literatura, que para Pound (2007, p.24) "é simplesmente a linguagem carregada de significado até o máximo grau possível".

Dentro deste processo de significação ao grau maior, o autor acredita ser possível identificar o que ele chama de modalidades de poesia - ou literatura - que seriam espécies de ferramentas utilizadas pelos grandes escritores para alcançar a obra máxima. São elas a fanopeia, a melopeia e a logopeia. Segundo Pound (2007, p.41), a primeira está diretamente ligada ao uso de "uma palavra para lançar uma imagem visual na imaginação do leitor". Ou seja: esmero na escolha das palavras e na concatenação entre elas tornam-se capazes de projetar visualmente uma imagem pretendida pelo escritor, em cuidadoso processo descritivo, caracterizando a tradução do poder visual da imagem. Amelopeia, em outra frente, consiste na saturação de um som e na arte de musicar a poesia - tal como na arte dos trovadores - para obter o efeito da significação. Por fim, Pound criva a logopeia - que ele relaciona aos escritores que ele chama de sofisticados, que ele resume como "a dança do intelecto entre as palavras", que trabalha no domínio específico das manifestações verbais, relacionado ao tipo de contexto em que o leitor espera ou está habituado. Ou seja, o bom escritor deve se valer de vocábulos e de estruturação textual sintonizados suficientemente para promover um rico e detalhado vislumbre metafísico no receptor. 
É nesse cuidado descritivo que se insere outro conceito ligado à retórica: a ekphrasis. Do grego phrasô, fazer entender, e $e k$, até o fim, a ekphrasis, segundo Hansen (2006, p.1) era usada nos progymnasmata, 'exercícios preparatórios de oratória escrito por retores gregos entre os séculos I e IV d.C.'. Os mesmos eram influenciados, dentre outros, pelos aspectos epidíticos da ekphrasis, ou seja, aspectos explicativos, demonstrativos, com nuances de ostentação. Ainda segundo Hansen,

Aélio de Theon diz que a ekphrasis é discurso periegético - que narra em torno - pondo sob os olhos com a enargeia, 'vividez', o que deve ser mostrado. Nos seus Progymnasmata, Hermógenes a define de maneira semelhante: ténica de produzir enunciados que têm a enargeia, presenteando a coisa quase como se o ouvido visse em detalhe (HANSEN, 2006, p.85).

Devido a esta íntima relação entre a ekphrasis e a descrição acurada de algo, ela foi aplicada por poetas que tinham nas obras de arte sua inspiração para exercer a arte da descrição. De acordo com Hansen (2006, p. 2), neste caso "o narrador, pois, se colocaria como intérprete da interpretação que o pintor fez da sua matéria".

Para Hansen, no entanto, hoje o termo passou a ser aplicado nas mais diversas áreas, incluindo outros tipos de arte ou ainda áreas de estudos.

Hoje, em tempos de desistoricização, o termo ekphrasis é usado para significar qualquer efeito visual. Da biologia à música, passando pela arqueologia, pela física, pela história literária, pela informática e por estudos culturais de gênero, o termo é usado fora dos seus usos retóricos antigos, significando "efeito sensorial”, 'visualização', ‘iconização', ‘espetacularização', 'realidade virtual' (HANSEN, 2006, p.87).

Dentro desta lógica, é plenamente possível fazer uma analogia na qual o diretor Philip Kaufman faz as vezes do narrador, que se coloca como interpretador da interpretação que Tom Wolfe fez, por meio do jornalismo literário, do Projeto Mercury. Em suma, o trabalho 
essencialmente descritivo - ou ekphrástico - do jornalista evocou as imagens visuais (leia-se fanopeia) que foram traduzidas em imagens pelo diretor. Ao fim e ao cabo, Kaufman também acaba se apoiando no exercício da ekphrasis, quando partindo das palavras carregadas de significação contidas no trabalho de Wolfe descreve visualmente o cenário de guerra, valendo-se da linguagem cinematográfica.

Em seu capítulo sobre ekphrasis, no livro Picture Theory, W.J.T. Mitchell (1994, p.152) afirma que a literatura pode refletir, dependendo do seu grau de qualidade, o que ele denomina de esperança ekphrástica, que permite ao leitor, por meio da construção imaginária ou metafórica, descobrir um sentido no qual a linguagem pode fazer o que muitos escritores desejam: fazer o leitor ver, mesmo que não esteja no espaço físico ou temporal da ação descrita.

Por se tratar de conceitos intimamente ligados à projeção visual, o presente artigo é uma tentativa de trazê-los e adaptá-los para um tipo de literatura específica - o Jornalismo Literário - e para a transposição dela para o cinema. A verve extremamente descritiva de ambos - cada qual em sua plataforma e com as suas características próprias e intrínsecas - são o ponto de aproximação conceitual com a ekphrasis e a fanopeia.

\section{Da palavra à imagem}

Como objeto de análise, tomou-se o livro-reportagem Os eleitos (The RightStuff), escrito por Tom Wolfe após uma série de entrevistas e coberturas jornalísticas do Projeto Mercury, desenvolvido pela Nasa nos anos 60. Como pano de fundo da história dos audaciosos pilotos que se tornaram os primeiros astronautas a irem ao espaço, está a disputa espacial entre Estados Unidos e a então União Soviética, no auge da Guerra Fria. O livro foi adaptado para o cinema em 1983, pelo roteirista e diretor Philip Kaufman, com o apoio de Wolfe no argumento. Como de praxe, houve algumas alterações em relação ao texto original na busca pela 
narrativa dramático-cinematográfica. Porém, cada obra, a seu modo, nos faz atuar como, no mínimo, espectador da história.

Como referência analítica e busca da aplicabilidade dos conceitos de ekphrasis e fanopeia no jornalismo literário toma-se um trecho do livro Os eleitos onde o autor descreve, detalhadamente, a visão que o piloto Glenn tem através do periscópio da cápsula, lembrando que Wolfe teve acesso às informações mediante uma série de entrevistas com os pilotos envolvidos no Projeto Mercury. Wolfe transpôs o diálogo para o livro da seguinte maneira:

Friendship 7 chamando - ele disse. - Vou tentar descrever o que está ao meu redor. Estou no meio de uma grande massa de partículas minúsculas brilhantemente iluminadas como se fossem luminescentes. Nunca vi nada parecido. São redondas, um pouco. Estão se aproximando da cápsula, e parecem estrelinhas. Uma chuva delas se aproximando. Rodopiam em torno da cápsula e diante da janela e estão todas brilhantemente iluminadas. Provavelmente estão separadas uns dois ou três metros entre si em média, mas posso vê-las abaixo da cápsula também (WOLFE, 1992, p.289).

No livro, e o que se pressupõe, na realidade, a cabine de comando não deu muita atenção ao deslumbramento inicial de Gleen que continuou descrevendo a cena para a cabine de comando em Cabo Canaveral, de onde partiam as principais informações para o piloto. Com cuidado descritivo acurado, o autor utiliza palavras de verdadeira evocação visual (fanopeia), com a força descritiva característica da ekphrasis. Segundo Wolfe, foi assim que o piloto contou o que via pelo vidro da cápsula.

Rodopiavam em torno da cápsula como minúsculos diamantes imponderáveis - joinhas - não, pareciam mais vaga-lumes. Tinham um movimento vagaroso mas errático, e quando focalizava uma parecia estar iluminada, mas a luz se apagava e ele a perdia de vista, e em seguida tornava a se iluminar. Isso lembrava os vagalumes também. Costumava haver milhares de vagalumes durante os verões de sua infância [...] Indiscutivelmente eram 
partículas de algum tipo, partículas que refletiam luz solar em determinado ângulo. Eram lindas, mas estariam saindo da cápsula? (WOLFE, 1992, p.290).

A representação da realidade transposta para o livro ganhou uma nova versão, desta feita imagética, pelas mãos do diretor Philip Kaufman, que teve o apoio do autor Tom Wolfe na construção do argumento. Talvez, por esse motivo, haja tanta fidedignidade à obra original. Com um elenco expressivo, composto por nomes como Sam Shepard, Ed Harris e Denis Quaid, o filme foi indicado a oito Oscar e venceu nas categorias Montagem, Som, Edição de Som e Trilha Sonora. A despeito de ter perdido o prêmio de Melhor Fotografia para Fanny e Alexandre, o diretor de fotografia Caleb Deschanel valeu-se do cuidado descritivo da história original para criar os conceitos visuais do filme, num exercício ekphrástico de descrição e de transposição de uma forma de arte a outra. No aspecto da fanopeia, o efeito provocado reflete na analogia entre obra original e obra cinematográfica. Entretanto, por se tratar de uma adaptação, o diretor e roteirista incluiu algumas informações que, visualmente, causam um efeito semântico que permite uma interpretação conotativa na relação entre tecnologia e misticismo e entre conceitos vinculados à antropologia, que ao passo que delimitam, aproximam homens de diferentes polos do mundo.

Como metodologia de análise cinematográfica do presente trabalho, pautou-se na proposta de Michel Marie, detalhada por Vanoye e Goliot-Lété (1994). Primeiramente, parte-se para a numeração do plano, levando-se em conta a duração e/ou numero de fotogramas. Depois, é mister ater-se aos elementos visuais representados - neste artigo, esta é a etapa analítica mais acurada. Inclui-se ainda a observação da escala de planos, incidência angular, profundidade de campo e movimentos de câmera - ou seja, elementos diretamente vinculados à direção de fotografia; passagens de plano, afeitos à montagem e trilhas sonoras e relações diegéticas entre som e imagem. 
A sequência recortada para análise começa com o sinal de falha no escudo térmico de proteção de Gleen (interpretado por Ed Harris) e termina com uma projeção mística da solução do problema, com contraponto entre tecnologia e culturas e crenças arcaicas.

Na primeira delas (Figura 1), que se passa na sala de comando principal da missão em Cabo Canaveral, um plano fechado mostra a luz de alerta do escudo térmico da mesa de comando piscando, ora branco, ora vermelho. De modo automático, o espectador percebe que há algo errado - o que é reforçado pela cena sequencial, que mostra Al Shepard com o olhar apreensivo e um diálogo carregado de tensão entre ele e o comandante da missão. Partindo-se para os elementos visuais representados, temos o sentido conativo de emergência, que a paz outrora representada pela projeção espacial se rompe. O paradigma da luz piscando, em branco e vermelho, ganha um sentido conotativo ao associar-se à escrita no botão e as posteriores feições das personagens. Em suma, há algo errado acontecendo.

Figura 1 - O piscar da luz de alerta no capcom em Cabo Canaveral descreve claramente que o funcionamento da nave do piloto Gleen está comprometido

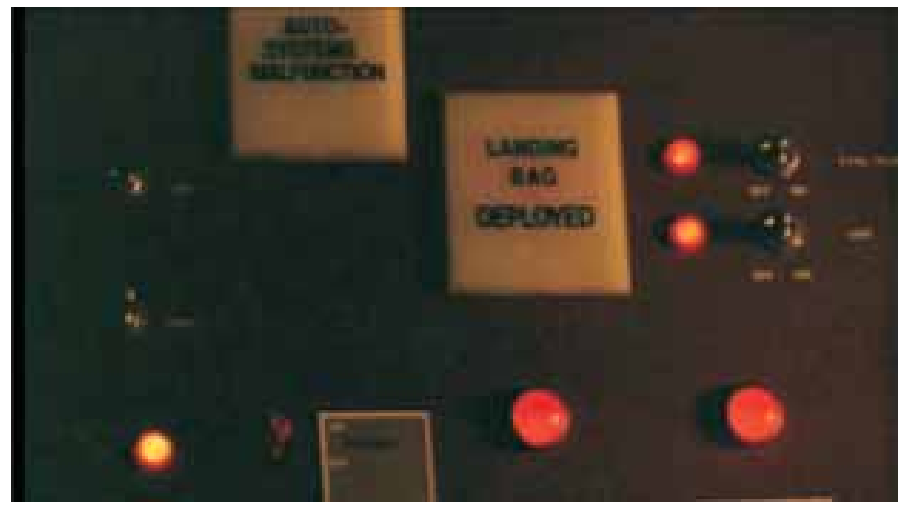

Fonte: Os eleitos (The RightStuff, 1983).

Como contraponto ao clima de apreensão na cabine de comando, Gleen olha tranquilamente pelo periscópio da nave, tendo como vista uma 
profusão de azul e nuvens - algo que remete à tranquilidade, à paz. Na película - diferente do que será visto na análise comparativa entre a obra literária e cinematográfica - a cabine de comando se dá conta do problema antes do piloto. E há toda uma construção poético-imagética que se segue nas cenas posteriores. A começar pela sequência marcada pelo que se pode observar na Figura 2.

Na calada da noite, em um povoado no interior da Austrália, é possível ver a cabine de comando improvisada, tendo como elemento denotativo uma antena de transmissão - deduz-se, automaticamente, que aquele prédio no meio do nada é uma cabine de comando do projeto. A cena é complementada por um sem número de fagulhas provenientes da fogueira acesa pelos aborígenes, que realizam um ritual ancestral concomitantemente com a missão espacial do Projeto Mercury. $\mathrm{O}$ diretor se utiliza de uma licença poética ao incluir o ritual aborígene no roteiro ele sequer é mencionado no livro. A manobra, supõe-se, faz parte da magia do cinema, que permite por meio de imagens em movimento, evocar referência como a contraposição entre o antigo e o moderno, o científico e o místico.

Figura 2 - O contraponto entre a tecnologia, representada pela parabólica, e as fagulhas do ritual aborígene, que serão usadas analogicamente às partículas saídas da cápsula

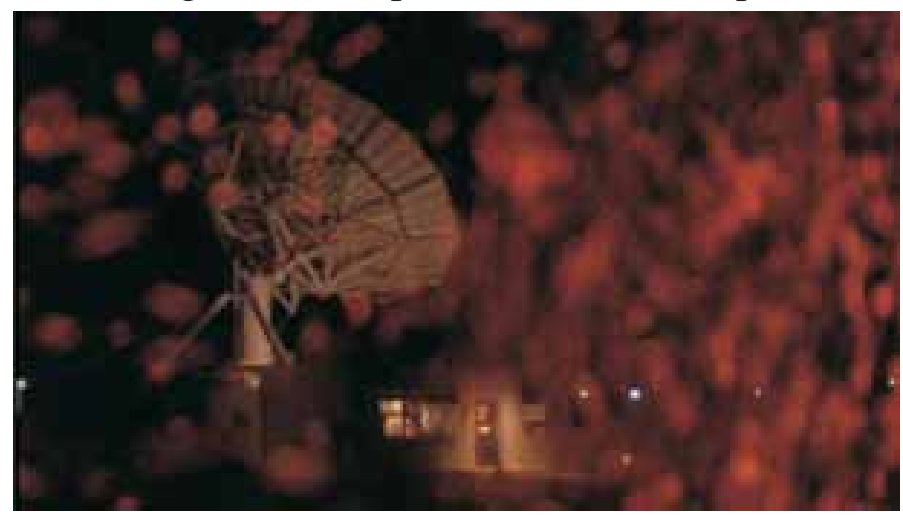

Fonte: Os eleitos (The RightStuff, 1983). 
As partículas de fogo partem em direção ao espaço e dão o tom para a cena seguinte (Figura 3), que mostra Gleen observando partículas semelhantes pelo periscópio, deslumbrado - a descrição deste momento, no livro, foi apontada no presente artigo. Vale prestar atenção no plano utilizado pelo diretor, que dá a real noção da instabilidade da cápsula - o quadro é diagonal, causando desequilíbrio. Por se valer do apoio visual, o extenso parágrafo ekphrástico, primorosamente descritivo, a cena é muito mais simples de ser representada.

Figura 3 - Encantado com as partículas luminescentes que vê pelo periscópio, Gleen passa a descrevê-las ao capcom

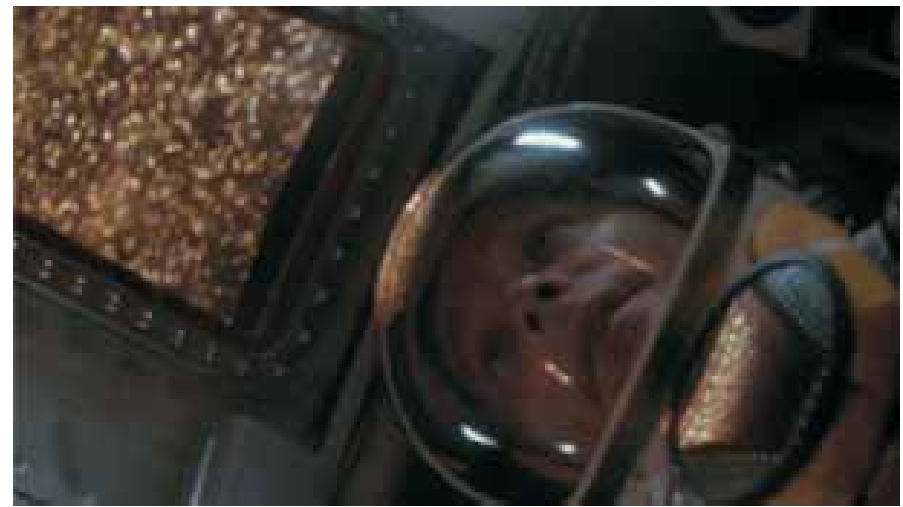

Fonte: Os eleitos (The RightStuff, 1983)

O sentido de instabilidade, desequilíbrio, é pontuado pela cena de sequência, que em plano aberto mostra a cápsula de Gleen no espaço, escuro, permeado pelas partículas desprendidas pela nave. Quando incluí os planos e enquadramentos no seu processo analítico, é sobre isso que Michel Marie fala: das sensações que a imagem cinematográfica provoca, no eixo sintagmático.

Como complementação, o diretor nos oferece as efetivas cenas do ritual que, em uma interpretação livre, poderia ter contribuído para o desfecho bem sucedido da missão de Gleen, que volta à Terra depois de bater o recorde de órbitas em torno do planeta. 
Figura 4 - A cena é formada pela cápsula em meio às partículas que saem do escapamento, o que virá a ser montado com a cena das fagulhas do ritual aborígene

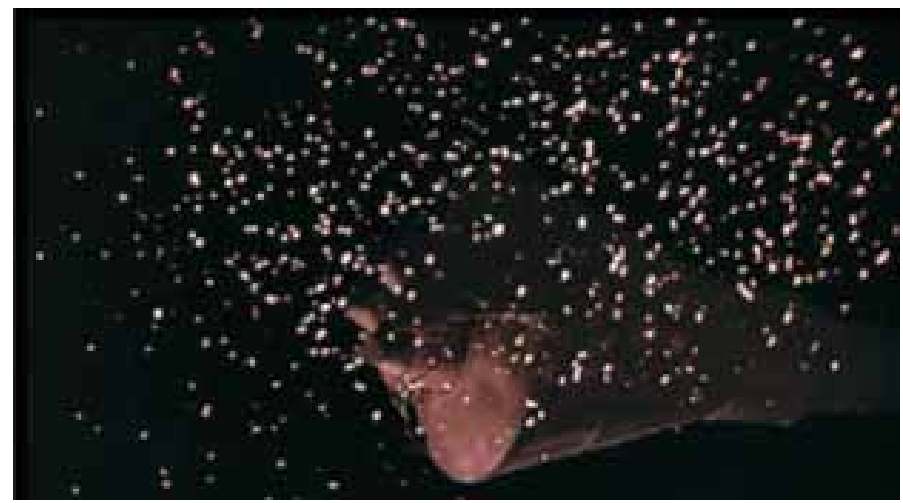

Fonte: Os eleitos (The RightStuff, 1983)

Figura 5 - As fagulhas da fogueira usada no ritual são mandadas para o alto, como se fossem encontrar as fagulhas da cápsula onde Glenn viaja

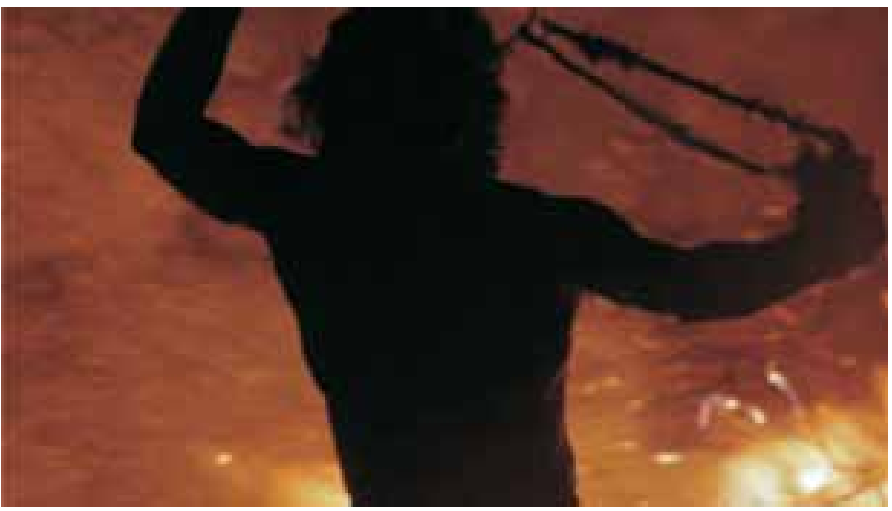

Fonte: Os eleitos (The RightStuff, 1983)

Em síntese, partindo dos aspectos apontados por Marie como fundamentais no processo de análise fílmica, temos elementos muito marcantes na cena, como o simbólico fogo, ora partindo do ritual aborígene, ora partindo da cápsula. Há ainda o contraponto entre o místico e o científico, que a despeito de não estar presente no livro que deu origem ao 
filme, registra um aspecto ficcional da obra, que é uma adaptação de uma história real, já romanceada, para o cinema.

Em outra frente, é possível perceber fortemente a tradução imagética dos fragmentos do texto de Wolfe por meio da força descritiva do trabalho do autor e suas palavras carregadas de significados, versados nos conceitos de evocação visual da fanopeia e no poder descritivo da ekphrasis, e se fortalece na transposição descritiva do texto escrito de Herr ao texto imagético de Kaufman e Deschanel.

\section{Considerações finais}

A despeito de tratarem de uma mesma temática - o Projeto Mercury - as obras literária e cinematográfica de Os eleitos convergem e divergem em alguns momentos, especialmente em função da plataforma a que pertencem - leia-se narrativas diversas. Segundo Stam (2008), é comum à crítica cinematográfica ser "extremamente discriminatória, disseminando a ideia de que o cinema vem prestando um desserviço à literatura". Porém para o autor,

A passagem de um meio unicamente verbal como o romance para um meio multifacetado como o filme, que pode jogar não somente com palavras (escritas e faladas), mas ainda com música, efeitos sonoros e imagens fotográficas animadas, explica a pouca probabilidade de uma fidelidade literal, que eu sugeriria qualificar até mesmo de indesejável (STAM, 2008).

Uma vez dado este salvo-conduto, que justifica a inclusão de fatos do filme que não estavam na obra original, podemos concluir que um importante ponto de convergência entre as duas obras está no sentido adaptado de ekphrasis e fanopeia, explorados na obra literária de Wolfe e que podem ser aplicados à versão cinematográfica da obra, que, grosso modo, faz as vezes de tradução imagética do texto à tela. Vale lembrar que Hansen afirma que, "na ekphrasis, o narrador se define como 
intérprete (exégetes) da interpretação que o pintor fez da sua matéria”. Aplicando o raciocínio de modo análogo para o cinema, podemos ver o diretor como intérprete da interpretação que o autor fez da realidade ao transpô-la, a partir de suas percepções, ao livro-reportagem.

Ao fim e ao cabo, o que vale é lembrar o sentido descritivo da representação da realidade, em ambos os casos, e como essa descrição é feita detalhadamente por Tom Wolfe para provocar nossa visualização metafísica dos sentimentos de Gleen em seu voo em órbita ao redor da Terra. E como em um sentido contrário ao texto que parte de uma pintura - vinculada aos primeiros trabalhos da ekphrasis - o diretor Philip Kaufman se vale da liberdade de traduzir imageticamente o que estava escrito em código linguístico no livro-reportagem Os eleitos.

Não cabe aqui um veredicto sobre o que é melhor - livro ou filme. $\mathrm{O}$ que vale é perceber como, cada qual a sua maneira, consegue, descritivamente, evocar imagens e interpretações para seus receptores. $\mathrm{E}$ nisso, pode-se dizer, tanto Wolfe quanto Kaufman, cada um manejando a sua forma de arte, são bem sucedidos, ao final das contas.

\section{Referências}

HANSEN, João Adolfo. Categorias epidíticas da ekphrasis. Revista USP, São Paulo, n.71, p.85-105, 2006.

JOHNSON, Michael L. El nuevo periodismo. Buenos Aires: Troquel, 1975.

MITCHELL, William John Thomas. Picture theory. Chicago: The University of Chicago Press, 1994.

OS ELEITOS. Direção: Philip Kaufman. Produção: Irwin Winkler e Robert Chartoff. Estados Unidos: Warner Bros Entretainement, 1983. 2 DVD (193 min), son. col. 
POUND, Ezra. ABC da literatura. 10. ed. São Paulo: Cultrix, 2007.

STAM, Robert. A literatura através do cinema: realismo, magia e arte da adaptação. Belo Horizonte: Editora UFMG, 2008.

VANOYE, Francis; GOLIOT-LÉTÉ, Anne. Ensaio sobre a análise fílmica. Campinas: Papirus, 1994.

WOLFE, Tom. Os eleitos. Rio de Janeiro: Rocco, 1992.

WOLFE, Tom. Radical chique e o novo jornalismo. São Paulo: Companhia das Letras, 2005. 